УДК 378.147:351

I. В. Новіцька,

кандидат педагогічних наук

(Житомирський державний університет імені Івана Франка) inesanovicka@gmail.com ORCID: 0000-0003-0780-0580

А. А. Грушева, кандидат педагогічних наук, доцент (Національний університет державної фіскальної служби України, м. Ірпінь) gryshevska@ukr.net ORCID: 0000-0004-1120-1580

I. А. Вербовський, здобувач

(Житомирський державний університет імені Івана Франка) super iagrik2011@ukr.net ORCID: $0000-0009-0920-0910$

\title{
ТЕОРЕТИЧНІ ЗАСАДИ ФОРМУВАННЯ УПРАВЛІНСЬКИХ УМІНЬ У СТУДЕНТІВ ЗВО У ПРОЦЕСІ РОЗВ'ЯЗУВАННЯ ПРОФЕСІЙНИХ ЗАДАЧ
}

У статті подано теоретичний огляд наукової літератури з проблеми формування управлінських умінь у студентів ЗВО у процесі розв'язування професійних задач. Обтрунтовано та визначено умови, які покращують прочес формування управлінських умінь у студентів в усіх галузях професійної підготовки. Проаналізовано професійні уміння, які повинні бути сформовані у майбутнього фахівия-управліния, визначено структурні компоненти управлінських умінь. Доведено, щчо сьогодні конкурентоздатним на ринку праці може стати не стільки відмінник-теоретик, скільки практикозорієнтований спеціаліст.

Молодь повинна бути підготовлена до нових ролей у суспільстві, повинна змінюватися та пристосовуватися до нових потреб ринку праці, оперувати та управляти інформацією, активно діяти, швидко приймати рішення, навчатись упродовж життя.

Ключові слова: професійна підготовка, управлінські уміння, управлінська компетентність, конкурентоспроможність фахівия.

Постановка проблеми у загальному вигляді та її зв'язок із важливими науковими і практичними завданнями. Неодноразово науковцями було доведено про важливість і необхідність модернізації освіти України, зокрема зміцнення позицій у підготовці працівників, які креативно мислять, можуть знайти творче рішення будь-яких складних завдань. Сучасні умови підготовки студента закладу вищої освіти вимагають від нього компетентного мислення, уміння планувати, здійснювати, аналізувати спочатку педагогічний процес, а в подальшому творчий професійно-діяльнісний процес, який складається з нескінченного ряду задач і завдань, вирішення яких спрямоване на досягнення загальної мети підготовки фахівця. А саме, формування особистості, його світоглядних ідей, переконань, норм поведінки, норм планування та існування. Аналіз досліджень та вивчення стану формування управлінських умінь у студентів ЗВО засвідчує те, що рівень володіння управлінськими уміннями студентами закладів вищої освіти дещо не відповідає вимогам сучасного ринку праці. У зв'язку з цим важливого значення набуває підготовка майбутнього фахівця із сформованими та розвинутими управлінськими уміннями у процесі розв'язування професійних задач.

Аналіз основних досліджень і публікацій із зазначеної проблеми. Неспростовним є той факт, що останнім часом з боку науковців велика увага приділяється проблемі підготовки майбутніх фахівців. Так, проблемам управління інноваціями присвячені праці Даниленко Л. І., Сльникової Г. В., Калініної Л. М., Маслова В. І. Пікельної В. С. та ін. У відомих працях Конаржевського Ю. А., Моісеєвої О. М., Поташника М. М., Третьякової П.І. та ін. висвітлено процес переорієнтації змісту управління загальноосвітнім навчальним закладом. Інноваційний розвиток системи освіти, ii особистісні переорієнтації, саму концепцію розвитку управлінської системи розглядами Андрущенко В. П., Зязюн І. А., Савченко О. Я., Саух П. Ю. тощо.

Питаннями формування професійних умінь, зокрема управлінських умінь у майбутніх спеціалістів, займалися як вітчизняні, так i зарубіжні дослідники. Аналіз останніх психолого-педагогічних досліджень свідчить про постійне зростання інтересу до проблеми формування управлінських умінь у студентів ЗВО у процесі розв'язування професійних задач. В останні роки виконано ряд досліджень суміжної тематики, у яких розглядається: процес формування економічної культури студентів в професійній підготовці (Тандир Л. В.), процес формування управлінських умінь майбутніх вчителів у позанавчальній діяльності (Сердюк Н. Ю.), розвиток професійних умінь і здібностей (Клочко А. М.); процес формування управлінських умінь і навичок (Сікорська Л. О.), підготовка студентів до

(C) Новіцька I. В., Грушева А. А., Вербовський I. А., 2018 
педагогічного самоменеджменту в професійній діяльності (Мусієнко-Репська В. І.) та ін.

Однак, недостатня увага приділена дослідженню процесу формування управлінських умінь у студентів ЗВО у ході розв'язування професійних задач.

Формулювання мети і завдань статті. 3 огляду на вищезазначене, метою статті $є$ аналіз та представлення процесу формування управлінських умінь у студентів ЗВО у процесі розв'язування професійних задач.

Виклад основного матеріалу з обтрунтуванням отриманих наукових результатів. На сьогодні усе зрозумілішим стає той факт, що не тільки теоретичні знання, а й сукупність їх із практичними знаннями, вміннями та навичками, переконаннями $є$ найважливішим показником усебічно підготовленого фахівця. Важливим компонентом підготовки сучасного фахівця $€$ формування його особистісних умінь і навичок, пов'язаних із новими мотиваціями, організацією власної діяльності, створенням позитивної атмосфери колективу та вмінням працювати в ньому, здатністю ефективно діяти в умовах невизначеності та робити свідомі рішучі кроки. Практика свідчить, що кожний член колективу повинен уміти прогнозувати хід і результати власної та колективної діяльності, планувати, організовувати різноманітні форми роботи

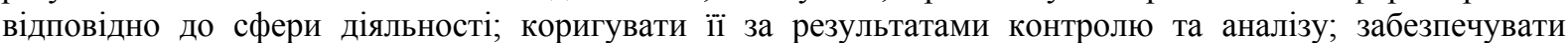
всебічний розвиток і формування необхідних особистісних якостей; співпрацювати 3 колегами, керівництвом, громадськістю. Так, кожен фахівець у своїй щоденній професійній діяльності виконує основні функції управління - аналіз, прогноз, організація, регуляція, коригування, контроль, аналіз виконання яких вимагає сформованих відповідних знань, управлінських умінь, навичок, здібностей і готовності до управління. Отже, підготовка студентів ЗВО до професійної діяльності в сучасних ринкових умовах $\epsilon$ неможливою без формування управлінських умінь.

Новий етап соціально-економічного розвитку України XXI століття орієнтований на інноваційні технології, людські та інформаційні ресурси у всіх сферах діяльності. Сучасне виробництво та сфера послуг потребують фахівців нового покоління, здатних працювати в умовах нестійкої кон'юнктури та жорсткої конкуренції. У зв'язку з цим виникла нагальна потреба в розробці шляхів і засобів підготовки "багатопланового" випускника закладу вищої освіти.

Постійна глобалізація ринку праці та загальносвітові тенденції щодо нових принципів організації виробництва й сфери послуг змусили роботодавця визнати, що сучасний фахівець окрім суто професійних знань та технологічної кваліфікації, мусить бути професійно мобільним, оволодівати новими функціями та вирішувати нові завдання, що, свою чергу, базується на більш широких основах теоретичних знань та практичних навичках. Тому, еволюція світу праці вимагає постійного перегляду науково-педагогічних підходів до підготовки випускників ЗВО в бік інтеграції певних спеціальностей, формування різних компетентностей.

Доцільним для нашого дослідження буде доцільно зупинитися на визначені професійної підготовці

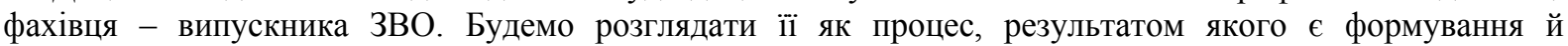
збагачення настанов, знань і умінь $з$ метою прискореного набуття навичок, необхідних майбутньому спеціалісту для адекватного виконання професійних завдань, а також сукупність певних особистісних якостей, досвіду праці та норм поведінки, що забезпечують можливість успішної роботи з обраної професії та подальшого професійного й особистісного розвитку. Крім того, це процес, результатом якого $€$ формування комплексу компетентностей, в тому числі формування усіх груп умінь, зокрема управлінських, необхідних майбутньому фахівцю для адекватного виконання професійних завдань, а також сукупність певних особистісних якостей, досвіду праці та норм поведінки, що забезпечують можливість успішної діяльності з обраної професії та подальшого професійного й особистісного розвитку. Професійна підготовка компетентного фахівця, готового до роботи в умовах постійно зростаючої конкуренції на ринку праці, визначена головною метою професійної освіти.

Щоб підготувати такого фахівця, необхідно сформувати в нього уміння оперувати такими технологіями та знаннями, що задовольняють потреби інформаційного суспільства. Молодь повинна бути підготовлена до нових ролей у суспільстві. Це означає вміння змінюватися та пристосовуватися до нових потреб ринку праці, оперувати та управляти інформацією, активно діяти, швидко приймати рішення, навчатись упродовж життя [1: 7].

Оскільки фахівець високого рівня - це компетентний спеціаліст, який у своїй діяльності процес удосконалення управлінської компетентності пов'язує із стрімкими соціально-економічними процесами, які відбуваються в країні, то структурними компонентами управлінських умінь, які при цьому необхідні, будуть: знання форм та методів управління; готовність і здатність ефективно проектувати й здійснювати управлінську діяльність 3 використанням знань, умінь і навичок, а також мотивації та особистісних якостей, необхідних для успішного управління; готовність до діалогу позицій суб'єктів освітнього процесу; інтегральна характеристика керівника, що відображає якість і рівень засвоєння компетенції управлінської діяльності на оперативно-тактичному рівні, визначається певними вимогами, обсягом управлінських функцій, умовами управлінської діяльності, уявленнями про ефективність цієї діяльності; функціональна грамотність тощо. Крім того, для досягнення успіху сучасному фахівцю необхідно мати 
не тільки високу кваліфікацію, але й певні переваги над іншими, певний комплекс умінь та особистісних якостей, а саме: відповідальність; комунікативність; організованість; здатність до самоуправління; інноваційність; творчість; цілеспрямованість; уміння впливати на колектив і переконувати; високий рівень мотивації до неперервного навчання; демократичність; готовність до ризику.

Практика вищої професійної підготовки фахівців різних галузях діяльності свідчить, що сьогодні конкурентоздатним на ринку праці може стати не стільки відмінник-теоретик, скільки практикозорієнтований спеціаліст. Аналізуючи ряд досліджень, виділяємо професійні уміння, які повинні бути сформовані у майбутнього фахівця-управлінця: визначати пріоритетність загальних цілей перед особистими; планувати, організовувати, мотивувати й контролювати власну діяльність; ризикувати та приймати обгрунтовані якісні рішення; визначати чіткі виробничі цілі і формулювати ціннісні орієнтири; використовувати принципи і методи ефективної управлінської праці та наукові підходи до управління колективом; володіти спеціальною та управлінською компетентністю; відбирати, аналізувати, узагальнювати та оцінювати інформацію; впроваджувати заходи 3 удосконалення управлінського документування та контролю за проходженням і виконанням документів; працювати в команді; управляти собою; розуміти та поважати інших; передбачати наслідки того чи іншого рішення; визначати систему мотивації працівників; делегувати повноваження; створити умови для розвитку кожного члена колективу тощо.

Якщо зупинятися на педагогічній діяльності, то важливою умовою формування управлінських умінь педагога визначає результативність реалізації особистісно орієнтованого підходу в навчанні. А саме підготувати науково-педагогічного працівника 3 високим рівнем культури; гуманною педагогічною позицією; розвинутими творчими здібностями; вмінням створювати й постійно збагачувати культурноінформаційне й предметно-розвивальне освітнє середовище; вмінням використовувати різноманітні педагогічні технології і при цьому надавати їм особистісно розвивальну спрямованість; ціннісним ставленням до студента як особистості [2]. Особистісно орієнтована система освіти дозволяє формувати особистість не лише за заданими рисами, а створити умови для повноцінного виявлення та розвитку особистісних функцій суб'єктів освітнього процесу, а це дозволить вистояти фахівцю в умовах глобалізації, в посиленні конкурентоспроможності та підвищенні мобільності в сучасному світі [3]. Набуті знання, уміння й навички під час навчання в реальному житті спрямовані на трансформацію в компетентності. Молодь потрібно готувати до нових професій та ролей у суспільстві, тобто випускник 3ВО має вміти змінюватися та пристосовуватися до нових потреб ринку праці, оперувати та управляти інформацією, активно діяти, швидко приймати рішення, навчатись упродовж життя $[4 ; 5 ; 6 ; 7]$. Однак в умовах модернізації системи професійної освіти залишається актуальною та набуває нової якості проблема наявності знань і умінь їх реалізувати на практиці. Адже в результаті реалізації традиційного підходу до підготовки фахівців у вищих навчальних закладах виникла ситуація, коли країна має велику кількість спеціалістів 3 вищою освітою, а реальній економіці бракує кваліфікованих практикозорієнтованих спеціалістів, здатних у своїй повсякденній діяльності реалізувати управлінські функції.

Отже, соціальне замовлення на фахівця з вищою освітою спонукає науково-педагогічні колективи до організації навчального процесу у ЗВО на основі компетентнісного підходу. Тому постійно повинна здійснюватися між предметна координація і узгодження роботи на рівні відповідних кафедр, викладачів при формуванні управлінських умінь (УП) майбутніх спеціалістів, а саме: виділення менеджерських (управлінських) аспектів фахової дисципліни; роз'яснення студентам змісту поняття УП та їх значення в майбутній професійній діяльності; реалізація міжпредметних зв'язків у процесі проведення групових форм навчання, виконанні індивідуальних завдань в процесі організації систематичної самостійної роботи студентів; проведення занять з використанням методів навчальної діяльності, що актуалізують міжпредметні зв'язки (моделювання ситуацій, круглі столи за матеріалами індивідуальної роботи, майстер-класи, дискуси, наукові роботи тощо); збільшення частка самостійної роботи студентів 3 різних навчальних дисциплін, що дозволить сформувати вміння систематизувати, планувати, контролювати й регулювати свою діяльність без допомоги й контролю викладача.

Оскільки випускник ЗВО може працювати в організації, на підприємстві, обіймаючи посаду відповідно до свого фаху, і може в майбутньому стати керівником, він повинен знати технологію менеджменту, як впливати на підлеглих, які методи використовувати, для досягнення максимально високих результатів, як сформувати свій колектив тощо. Тому навички володіння методами управління та організації роботи колективу посідають чільне місце в змісті професійної підготовки.

Висновки та перспективи подальшого дослідження проблеми. Таким чином, процес формування управлінських умінь у студентів ЗВО у процесі розв'язування професійних задач вимагає розробки певних методик, технологій підготовки фахівців у закладах вищої освіти, що забезпечать розвиток професійного мислення, здатності розв'язувати завдання, максимально наближені до професійних. А це дозволить розв'язати в найближчому майбутньому проблему підготовки особистісно орієнтованого фахівця високого касу. 


\section{СПИСОК ВИКОРИСТАНИХ ДЖЕРЕЛ ТА ЛІТЕРАТУРИ}

1. Овчарук О. В. Розвиток компетентнісного підходу : стратегічні орієнтири міжнародної спільноти / Оксана Василівна Овчарук // Компетентнісний підхід у сучасній освіті: світовий досвід та українські перспективи / заг. ред. О. В. Овчарук. - К., 2004. - С. 6-15.

2. Бондаревская Е. В. Гуманистическая парадигма личностно-ориентированного бразования / Евгения Васильевна Бондаревская // Педагогика. - 1997. - № 4. - С. 11-17.

3. Уйсімбаєва Н.В. Формування професійної компетентності майбутніх економістів в процесі науководослідної роботи у вищих навчальних закладах I-II рівня акредитації : дис. ... канд. пед. наук : 13.00 .04 / Наталія Василівна Уйсімбаєва. - Кіровоград, 2006. - 189 с.

4. Лебедев О. Е. Компетентностный поход в образовании / О. Е. Лебедев // Школ. технологии. - 2004. - № 5. C. 3-12.

5. Орбан-Лембрик Л. Е. Психологія управління : [посіб.] / Лідія Ернестівна Орбан-Лембрик. - К. : Академвидав, 2003. - 568 с. (Алма-матер)

6. Вандер-Венде М. К. Болонская декларация: расширение доступности и повышение конкурентоспособности высшего образования в Европе [Электронний ресурс] / М. К. Вандер Венге // Высшее образование в Европе. - 2000. - Том XXV. - № 3. - Режим доступу : http://www.aha.ru/moscow64/educationalbook. - Назва з екрана.

7. Бажин И. И. Исследование систем управления / И. И. Бажин // Компакт-учебник. - Харьков : Консум, 2004. $-336 \mathrm{c}$.

\section{REFERENCES (TRANSLATED \& TRANSLITERATED)}

1. Ovcharuk O. V. Rozvytok kompetentnisnoho pidkhodu: stratehichni oriientyry mizhnarodnoi spil'noty [Development of Competent Approach: Strategic Guidelines for the International Community] / Oksana Vasylivna Ovcharuk // Kompetentnisnyi pidkhid u suchasnii osviti : svitovyi dosvid ta ukrains'ki perspektyvy [Competency Approach in Modern Education: World Experience and Ukrainian Perspectives] / zah. red. O. V. Ovcharuk. - K., 2004. - S. 6-15.

2. Bondarevskaia E. V. Humanisticheskaia paradyhma lichnostno-orientyrovannoho brazovaniia [The Humanistic Paradigm of Student-Centered Education] / Evheniia Vasilevna Bondarevskaia // Pedahohika [Pedagogy]. - 1997. № 4. - S. 11-17.

3. Uisimbaieva N. V. Formuvannia profesiinoi kompetentnosti maibutnikh ekonomistiv v protsesi naukovo-doslidnoi roboty u vyshchykh navchal'nykh zakladakh I-II rivnia akredytatsii [Forming Economic Competence of Future Economists during the Process of Scientific-Research Work in Higher Educational Institutions of the 1st and 2nd Levels of Accreditation] : dys. ... kand. ped. nauk : 13.00.04 / Nataliia Vasylivna Uisimbaieva. - Kirovohrad, 2006. $-189 \mathrm{c}$.

4. Lebedev O. E. Kompetentnostnyi pokhod v obrazovanii [Competetive Approach to Education] / O. E. Lebedev // Shkol. Tekhnolohii [School Technologies]. - 2004. - №5. - S. 3-12.

5. Orban-Lembryk L. E. Psykholohiia upravlinnia [Psychology of Management] : [posib.] / Lidiia Ernestivna OrbanLembryk. - K. : Akademvydav, 2003. - 568 s. (Alma-mater).

6. Vander-Vende M. K. Bolonskaia deklaratsiia : rasshyreniie dostupnosti i povysheniie konkurentosposobnosti vyssheho obrazovaniia v Evrope [Bologna Declaration : Expanding the Accessibility and Competitiveness of Higher Education in Europe] [Elektronnyi resurs] / M. K. Vander Venhe // Vyssheie obrazovaniie v Yevrope [Higher Education in Europe]. - 2000. - Tom XXV. - № 3. - Rezhym dostupu : http://www.aha.ru/moscow64/educationalbook. - Nazva z ekrana.

7. Bazhyn I. I. Issledovaniie system upravleniia [Management System Research] / I. I. Bazhyn // Kompakt-uchebnik [Compact Tutorial]. - Kharkov : Konsum, 2004. - 336 s.

Новицкая И. В., Грушева А. А., Вербовский И. А. Теоретические основы формирования управленческих умений у студентов ВУЗов в процессе решения профессиональных задач.

В статье представлен теоретический обзор научной литературы по проблеме формирования управленческих умений у студентов ВУЗов в процессе решения профессиональных задач. Обоснованы и определены условия, которые улучшают процесс формирования управленческих умений у студентов во всех областях профессиональной подготовки. Проанализированы профессиональные умения, которые должны быть сформированы у будущего специалиста-управлениа, определены структурные компоненты управленческих умений.

Доказано, что сегодня конкурентоспособным на рынке труда может стать не столько отличниктеоретик, сколько практикоориентованный специилист. Молодежь должна быть подготовлена к новым ролям в обществе, должна меняться и приспосабливаться к новым потребностям рынка труда, оперировать и управлять информацией, активно действовать, быстро принимать решения, учиться на протяжении жизни.

Ключевые слова: профессиональная подготовка, управленческие умения, управленческая компетентность, конкурентоспособность специиалиста. 


\section{Novitskaya I. V., Grusheva A. A., Verbovsky I. A. Theoretical Principles of the Managerial Skills Formation for Students of Higher Education in the Process of Solving Professional Problems.}

The article presents the analysis of research and study of the state of managerial skills formation concerning students of higher education institutions. The problem of inconsistency of the level of students' management skills with institutions of higher education with the requirements of the modern labor market is outlined. The purpose of the article is to analyze and present the process of forming the managerial skills of students of higher education institutions in the process of solving professional problems.

The professional training of a competent specialist who is ready to work in conditions of ever-increasing competition in the labor market is determined by the main goal of vocational education. Young people must be prepared for new roles in society, they must change and adapt to new labor market needs, operate and manage information, act actively, make quick decisions, and learn throughout their lives.

The article presents the structural components of managerial skills: knowledge of forms and methods of management; readiness and ability to effectively design and manage management using the knowledge, skills and abilities, as well as the motivation and personal qualities necessary for successful management; readiness for dialogue of the positions of subjects of the educational process; the integral characteristic of the manager, reflecting the quality and level of mastering the competence of management activities at the operational-tactical level, is determined by certain requirements, the volume of managerial functions, conditions of management, ideas about the effectiveness of this activity; functional literacy, etc. On the basis of the analysis of the scientific work, the general professional skills, which are formed by the manager, are presented.

Key words: professional training, managerial skills, managerial competence, specialist's competitiveness. 